\section{Oesophageal cancer incidence in 20-year follow-up in a population-based sample of 12000 middle-age men with or without Helicobacter pylori infection in Finland}

Two consensus reports on Helicobacter pylori (Hp), published recently in Gut, summarise the role of $\mathrm{Hp}$ gastritis in upper GI diseases, including gastric cancer (GCA). ${ }^{12}$ Although Hp gastritis definitely increases the risk of GCA as suggested in both reports, $\mathrm{Hp}$ is, on the other hand, also associated with a notable low incidence of oesophageal cancer (EC), of both adenomatous and squamous type.

In our earlier 15-year follow-up of a large population-based sample of males aged 50-65 years $(n=12016)$ from two Finnish cities, with or without $\mathrm{Hp}$, diagnosed in 1994-1996 by serological (IgG) Hp test (Biohit HealthCare, Helsinki, Finland), 57 GCA cases were recorded in the study population by the nationwide Cancer Registry during the follow-up. ${ }^{3}$ Of these cancers, 50 were in men and seven in those with and without $\mathrm{Hp}$, respectively. The relative standardised incidence ratio (RR) of GCA incidence in $\mathrm{Hp}$ positive compared with that in Hp-negative men, calculated with the Altman's procedure, was 6.0 (95\% CI 2.3 to 19.0$)$.

In a 20-year follow-up of the same population sample, 39 ECs appeared during the follow-up. Of these, 29 were in the Hp-negative subgroup (6625 men) and 10 in the Hp-positive subgroup (5391 men) (table 1). Of the cancers in Hp-negative and in Hp-positive subgroups, 11 and three were ECs of adenocarcinoma type and 14 and six of squamous cell type, respectively. In five cases, the histological type was unknown. All estimates of RR of EC in the Hp-positive men compared with EC in the Hp-negative men were very low, as shown in table 1 , indicating that the $\mathrm{Hp}$ gastritis associates strongly with reduced EC risk. In addition to ECs of adenocarcinoma type also, the RR of squamous cell EC was notably low (table 1). Serum level of pepsinogen I did not markedly alter any of the RR estimates.

The prevented fraction of EC due to Hp positivity was very high, $78 \%$. In comparison, the corresponding attributable percentage of GCA in Hp-positive men was $84 \%{ }^{3}$ Thus, relatively, the Hp gastritis reduces EC incidence roughly similarly as it increases GCA incidence. However, the incidence rate of GCA in the present study population was nearly twice as high as the incidence of EC. Therefore, the numbers of GCA caused by Hp positivity were nearly twice the numbers of EC prevented by $\mathrm{Hp}$ positivity.

Lower than the expected risk of oesophageal cancer in men with $\mathrm{Hp}$ gastritis has been presented in several other studies (see, eg, Nie et al, Rokkas et al, Islami and
Kamangar, Xie et al, Ye et al, de Martel et al, Whiteman $e t a l^{4-10}$ ) The reason of this low risk is unknown. So far, the most plausible explanation is the intragastric acidity that tends to be lower in patients with $\mathrm{Hp}$ gastritis than in those without it. In people with 'healthy' stomach, a highly acid gastro-oesophageal refluxate, in persons prone and liable to GERD, may promote cascades that result in acid-related erosive and finally cancerous lesions in the oesophageal epithelium. In this context, in contrast to alkaline reflux, the acid reflux into the oesophagus is likely the key factor that associates with the increased risk and incidence of EC.

\section{Ilkka Juhani Vohlonen, ${ }^{1}$ Matti Hakama, ${ }^{2}$ Matti Härkönen, ${ }^{3}$ Nea Malila, ${ }^{4}$ Eero Pukkala, ${ }^{2}$ Veli Koistinen, ${ }^{5}$ Pentti Sipponen ${ }^{6}$}

${ }^{1}$ Department of Public Health, University of Eastern Finland, Kuopio, Finland

${ }^{2}$ Department of Epidemiology, Finnish Cancer Registry, Helsinki, Finland

${ }^{3}$ Department of Clinical Chemistry, University of Helsinki, Helsinki, Finland

${ }^{4}$ Department of Cancer Epidemiology, Finnish Cancer Registry, Helsinki, Finland

${ }^{5}$ Department of Biostatistics, Finnish Consulting Group, Helsinki, Finland

${ }^{6}$ Department of Pathology, Patolab Oy, Espoo, Finland

Correspondence to Professor Ilkka Juhani Vohlonen, Department of Public Health, University of

Eastern Finland, PO Box 1627, 70100 Kuopio, Finland; ilkka.vohlonen@uef.fi

Correction notice This article has been corrected since it published Online First. The $\mathrm{Cl}$ in the second paragraph has been updated to $6.0(95 \% \mathrm{Cl} 2.3$ to 19.0).

Contributors All authors have had a specific task in the processing of the study. IJV, as a team leader, was in charge of design and preparatory writing. $\mathrm{MH}$ was in charge of selecting the statistical procedures. MHN was in charge of implementing the laboratory tests. NM was in charge of analysing qualitatively the cancer register. EP was in charge of statistical analyses of cancer register. VK was in charge of calculating the RRs and the corresponding 95\% Cls. PS was in charge of qualitative assessment of differences between cardiac and oesophageal cancers.

Table 1 Numbers and relative standardised incidence ratios (RR and 95\% Cl) of oesophageal cancer in Helicobacter pylori (Hp) antibody (HpAb) positive and negative middle-age men from two cities followed up by National Cancer Registry in Finland from 1994 to 1996 to 2014

\begin{tabular}{|c|c|c|c|c|}
\hline & \multicolumn{2}{|l|}{ Hp status } & \multirow[b]{2}{*}{ Risk ratio (RR) } & \multirow[b]{2}{*}{$95 \% \mathrm{Cl}$ of $\mathrm{RR}$} \\
\hline & $\begin{array}{l}\text { Hp positive ( } \geq 30 \mathrm{HpAb} \text { (IgG) } \\
\text { enzyme immunoassay unit) }\end{array}$ & $\begin{array}{l}\text { Hp negative ( }<30 \mathrm{HpAb}(\mathrm{IgG}) \\
\text { enzyme immunoassay unit) }\end{array}$ & & \\
\hline Number of person years & $\begin{array}{l}107714 \\
(100810)^{*}\end{array}$ & $\begin{array}{l}89961 \\
(87461)^{*}\end{array}$ & & \\
\hline Squamous & 6 & 14 & 0.35 & 0.12 to 1.01 \\
\hline Other or unknown & 1 & 4 & - & - \\
\hline Total & $10(7)^{*}$ & $29(28)^{*}$ & 0.28 & 0.13 to 0.60 \\
\hline
\end{tabular}

${ }^{*}$ Numbers in brackets give the respective number of cases after excluding the men with atrophic gastritis (serum pepsinogen I <25 $\mu \mathrm{g} / \mathrm{L}$ ). 
Competing interests $\mathrm{MH}$ and PS are members of the Scientific Committee and shareholders of Biohit Oyj, a company which develops and markets laboratory tests, including biomarker tests for gastrointestinal diseases. MHN is a Board Member of the company. There are no other conflicts of interest.

Ethics approval The National Ombushman of Finland, the National Institute of Health and Wellfare and the Ethical Committee of the University Hospital of Eastern Finland.

Provenance and peer review Not commissioned; internally peer reviewed.

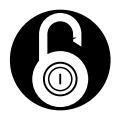

\section{OPEN ACCESS}

Open Access This is an Open Access article distributed in accordance with the Creative Commons Attribution Non Commercial (CC BY-NC 4.0) license, which permits others to distribute, remix, adapt, build upon this work non-commercially, and license their derivative works on different terms, provided the original work is properly cited and the use is noncommercial. See: http://creativecommons.org/licenses/ by-nc/4.0/
(C) Article author(s) (or their employer(s) unless otherwise stated in the text of the article) 2018. All rights reserved. No commercial use is permitted unless otherwise expressly granted.

\section{(A) Check for updates}

To cite Vohlonen IJ, Hakama M, Härkönen M, et al. Gut 2018;67:1201-1202.

Received 25 July 2017

Revised 15 August 2017

Accepted 20 August 2017

Published Online First 31 August 2017

Gut 2018:67:1201-1202.

doi:10.1136/gutjnl-2017-314913

\section{REFERENCES}

1 Malfertheiner P, Megraud F, O'Morain CA, et al. Management of Helicobacter pylori infection-the Maastricht V/Florence Consensus Report. Gut 2017;66:6-30.

2 Sugano K, Tack J, Kuipers EJ, et al. Kyoto global consensus report on Helicobacter pylori gastritis. Gut 2015;64:1353-67.

3 Vohlonen I, Pukkala E, Malila N, et al. Risk of gastric cancer in Helicobacter pylori infection in a 15-year follow-up. Scand J Gastroenterol 2016;51:1159-64.
4 Nie S, Chen T, Yang X, et al. Association of Helicobacter pylori infection with esophageal adenocarcinoma and squamous cell carcinoma: a meta-analysis. Dis Esophagus 2014;27:645-53.

5 Rokkas T, Pistiolas D, Sechopoulos P, et al. Relationship between Helicobacter pylori infection and esophageal neoplasia: a meta-analysis. Clin Gastroenterol Hepatol 2007:5:1413-7.

6 Islami F, Kamangar F. Helicobacter pylori and esophageal cancer risk: a meta-analysis. Cancer Prev Res 2008;1:329-38.

7 Xie FJ, Zhang YP, Zheng QQ, et al. Helicobacter pylori infection and esophageal cancer risk: an updated meta-analysis. World I Gastroenterol 2013;19:6098-107.

8 Ye W, Held M, Lagergren J, et al. Helicobacter pylori infection and gastric atrophy: risk of adenocarcinoma and squamous-cell carcinoma of the esophagus and adenocarcinoma of the gastric cardia. J Nat/ Cancer Inst 2004;96:388-96.

9 de Martel C, Llosa AE, Farr SM, et al. Helicobacter pylori infection and the risk of development of esophageal adenocarcinoma. J Infect Dis 2005:191:761-7.

10 Whiteman DC, Parmar P, Fahey P, et al. Association of Helicobacter pylori infection with reduced risk for esophageal cancer is independent of environmental and genetic modifiers. Gastroenterology 2010;139:73-83. 